\title{
Microstructure of Polymer Composite Materials
}

Martina Kalova ${ }^{1}$, Sona Rusnakova ${ }^{2}$

${ }^{1}$ Faculty of Metallurgy and Materials Engineering, VŠB - Technical University of Ostrava. 17. listopadu 15/2172, 708 33 Ostrava. Czech Republic. E-mail: kaloma13@seznam.cz

${ }^{2}$ Department of Production Engineering, Faculty of Technology, Tomas Bata University in Zlín. Nad Stranemi 4511, 760 05 Zlín. Czech Republic. E-mail: rusnakova@ft.utb.cz

This paper deals with problems connected with defects in polymer composite materials and the causes of their occurrences. The microstructure of polymeric materials with carbon and hybrid (carbon / aramid) reinforcement with an epoxy matrix is examined. The evaluation of the microstructures of the two types of composites was performed with the aid of a scanning electron microscope, as well as a 3D light microscope. Defects (dry spots, bubbles, pores,...) in the structure of the material significantly affect its properties, and the question of their elimination is also considered. In order to achieve the most favourable physical and mechanical properties, the production method for the composite materials is important. While preparing test samples, it was used manual lamination technology, where $45 \%$ volume fraction of fibre reinforcement could be achieved in the technological regularities.

Keywords: Polymer Composites, Carbon Fiber, Hybrid Fiber, Microstructure

\section{Acknowledgement}

This paper was created with the contribution of the projects Student Grant Competition SP 2017/58 Specific research in metallurgy, materials and process engineering and with the financial support of the internal grant of TBU in Zlin No. IGA/FT/2017/002 funded from the resources of specific university research.

\section{References}

[1] EHRENSTEIN, W. G. (2005). Polymerní kompozitní materiály, 351 p. Scientia, Prague. ISBN 978-80-86960-296.

[2] LIPTÁKOVÁ, T. (2012). Polymérné konštrukčné materiály, 189 p. University of Žilina, Žilina. ISBN 978-80554-0505-6.

[3] PTÁČEK, L. (2002). Nauka o materiálu II, 392 p. Akademické nakladatelství CERM, s.r.o. Brno. ISBN 80-7224568-3.

[4] HUlL, D., CLYNE, T. W. (1996). An Introduction to Composite Materials, 326 p. Cambridge University Press, Cambridge. ISBN 0-521-38855-4.

[5] AGARWAL, B. D., BROUTMAN, L. J. (1987). Vláknové kompozity, No. 1, 296 p. SNTL, Prague.

[6] NIU, M. C. Y. (1992). Composite Airframe Structures, 500 p. Conmilit Press Ltd., Hong Kong. ISBN 9789627128069.

[7] BAREŠ, R. (1988). Kompozitní materiály, 328 p. SNTL, Prague.

[8] WEN, M., LUO, J. (2015). Study on Mechanical Properties of the Composite Resin Matrix Fiber Reinforced. In: Manufacturing Technology, Vol. 15, No. 2, pp. $243-249$.

[9] VALASEK, P. MÜLLER, M. (2014). Picture Analysis of Failure Areas of Particle Composites. In: Manufacturing Technology Vol 14, No 3, pp. 474-478.

[10] ZOLTEK. CarbonFiber [online]. [cit. 2017-02-02]. WWW: $<$ http://zoltek.com/carbonfiber/>.

[11] MORGAN, P. (2005). Carbon fibers and their composites, 1153 p. Taylor \& Francis Group, Boca Raton, Florida. ISBN-10 0-8247-0983-9.

[12] KRETSIS, G. (1981). A review of the tensile, compressive, flexural and shear properties of hybrid fibre-reinforced plastics. Composites, Vol. 18, No. 1, pp. 13-23.

[13] SWOLFS, Y., GORBATIKH, L., VERPOEST, I. 2014). Fibre hybridisation in polymer composites: A rewiew. Composites: Part a., 67(14), pp. 181-200.

[14] PLASTIC CARBON COMPOSITE TECHNOLOGY. Hand lamination. [online]. [cit. 2017-02-10]. WWW: $<$ http://www.plastic.cz/technologie-rucni_laminace $>$. 
[15] JANČÁ̌̌, J. (2003). Úvod do materiálového inženýrství polymerních kompozitů, Vysoké učení technické v Brně, Brno. ISBN 80-214-2443-5.

[16] GUIDE TO COMPOSITES. Delivering The Futureof Composite Solutions. [online]. [cit. 2017-02-10]. WWW: $<$ http://www.gurit.com>.

[17] KORDCARBON. Produkty. [online]. [cit. 2017-02-03]. WWW: <http://www.kordcarbon.cz/>.

[18] VALASEK, P. (2016). Applications of Microscopy in Experimental Description of Glass Powder/Epoxy Systems. In: Manufacturing Technology, Vol 16, No 5, pp. 1183-1188.

Copyright (C) 2017. Published by Manufacturing Technology. All rights reserved. 